\title{
Side Effects of Methotrexate for Psoriasis Therapy
}

\author{
Melida Agustina ${ }^{1}$, Afif Nurul Hidayati ${ }^{1}$, Nurina Hasanatuludhhiyah ${ }^{2}$ \\ ${ }^{1}$ Department of Dermatology and venereology, Faculty of Medicine, Universitas Airlangga/Dr. \\ Soetomo General Academic Teaching Hospital Surabaya, Indonesia \\ ${ }^{2}$ Departement of Pharmacology, Faculty of Medicine, Universitas Airlangga, Surabaya, Indonesia
}

\begin{abstract}
Background: Psoriasis is a chronic and relapsing inflammatory disease of the skin, characterized by the presence of welldefined erythematous plaque covered by silvery-white scales. Methotrexate is a folic acid antimetabolic for psoriasis therapy and given systemically so unexpected effects can occur. Purpose: To evaluate the side effects of methotrexate as therapy in psoriasis. Methods: The descriptive research based on the medical record of psoriasis patients who were treated for hospitalization on at Kemuning I and II ward Dr. Soetomo General Academic Hospital Surabaya during the period January 2017 - December 2018. The sampling method used was total sampling. Result: Twenty two psoriasis patients receiving methotrexate therapy with the dose of methotrexate is $10-15 \mathrm{mg}$ once weekly, there were $4.5 \%$ low erythrocyte level, $27.3 \%$ high leukocyte level, 13.6\% high thrombocyte level, 18.2\% high SGOT level, 22.8\% high SGPT level, 18\% nausea, 9.1\% vomiting, $4.6 \%$ headache, and $4.6 \%$ shortness of breath. Conclusion: Methotrexate for psoriasis therapy may cause several side effects even not the severe ones, therefore careful dosing and side effect monitoring are necessary.
\end{abstract}

Keywords: psoriasis, methotrexate, side effects.

Correspondence address: Afif Nurul Hidayati, Department of Dermatology and Venereology, Faculty of Medicine Universitas Airlangga/ Dr. Soetomo General Academic Teaching Hospital, Surabaya, 60131, Indonesia. Phone: (031) 5501609, e-mail: afif_nurulhidayati@fk.unair.ac.id

\section{BACKGROUND}

Psoriasis is a relapsing chronic inflammatory disease of the skin, marked by the presence of a firmly demarcated erythema plaque covered by silvery-white scales. Symptoms that may occur are itchy or burning sensation on the lesion. ${ }^{1}$ The pattern of psoriasis includes psoriasis vulgaris, guttate psoriasis, inverse psoriasis, erythrodermic psoriasis, pustular psoriasis, sebopsoriasis, diaper psoriasis, and linear psoriasis. Psoriasis vulgaris is the most common form of psoriasis, which is observed in around $90 \%$ of patients. Psoriasis vulgaris is marked by the presence of erythema plaque that is covered by a thick white squama, the existence of phenomena of kaarsvlek, auspitz signs, and koebner signs. ${ }^{2}$

According to WHO in 2016, psoriasis is a global health problem. This is based on the results of reports from several countries ranging between $0.09 \%$ and $11.43 \%$, or about 100 million individuals affected worldwide. $^{3}$ Definite data for cases of psoriasis in Indonesia are not available, but psoriasis data are accessible from the results of previous studies. The prevalence of pustular psoriasis in Dr. Soetomo General Academic Hospital Surabaya on January 2001 - December 2011 were 21 cases. ${ }^{4}$ There were 48 cases of psoriasis all types in RSUP Prof. Dr. R. D Kandou Manado during the period of January - December 2012. ${ }^{5}$
A broad-spectrum psoriasis therapy, both topically and systemically is available. The treatment regimen is tailored to the extent of the disease and assessment of the severity of the disease. The principle of treatment strategy is only to control the severity of the disease and prevent a recurrence. ${ }^{2}$ Various topical therapies are safe and effective for mild to moderate psoriasis. More severe psoriasis requires systemic therapy, such as phototherapy, acitretin, methotrexate, cyclosporine, or biological agents. ${ }^{6}$

The more appropriate therapy for moderate to severe psoriasis is a systemic therapy. Methotrexate (MTX) is a systemic therapy agent that has high effectivity for moderate to severe chronic psoriasis. This medicine has strong antiinflammatory activity. ${ }^{2}$

Methotrexate can control the disease well and can improve the quality of life of psoriasis patients. ${ }^{7}$ Optimal effect of methotrexate generally in 5 to 6 months therapy. About 50-70\% of patients felt the good results of methotrexate therapy, which gave a $75 \%$ reduction in Psoriasis Area and Severity Index (PASI) score. $^{8}$

Methotrexate (MTX) is a folate antagonist that works to inhibit dihydrofolate reductase strongly and lasts a long time, thus causing inhibited synthesis of purines and pyrimidines. Dyhidrofolate reductase is an enzyme that catalyzes dihydrofolate $\left(\mathrm{FH}_{2}\right)$ to tetrahydrofolate $\left(\mathrm{FH}_{4}\right)$. Tetrahydrofolate is an active 
metabolite of folic acid which acts as an important cofactor in various carbon atomic transfer reactions in the synthesis of proteins and nucleic acids. ${ }^{9}$

This drug serves to reduce the synthesis of various proinflammatory cytokines such as Tumor Necrosis Factor (TNF- $\alpha$ ) dan interleukin-1 (IL-1). ${ }^{10,11}$ Besides pharmacotherapy, psychotherapy may also be useful in the treatment of psoriasis. ${ }^{12}$

Systemic methotrexate can affect the whole body so unexpected effects can occur. Unexpected effects of this medicine are anemia, leukopenia, nausea, oral ulceration, pneumonitis, hematopoietic suppression, disorders of the liver and kidney. ${ }^{1}$ One study also reported the appearance of oral ulcers on the buccal mucosa and a routine blood examination found low platelets. ${ }^{13}$

This was a descriptive study aimed to determine the side effects of methotrexate as a therapy in psoriasis patients treated in the Kemuning I and II Wards Dr. Soetomo General Academic Hospital Surabaya. The side effects analyzed in this study included the number of erythrocytes, leukocytes, platelets, Serum Glutamic Oxaloacetic Transaminase (SGOT), Serum Glutamic Pyvuric Transaminase (SGPT), and clinical complaints in psoriasis patients. This research is expected to be contributive for appropriate selection of psoriasis therapy that improved therapeutic results can be obtained.

\section{METHODS}

This was a descriptive study using medical records obtained from the inpatients of Kemuning I and II Wards Dr. Soetomo General Academic Hospital Surabaya between January 2017 and December 2018 as the secondary data, and the research material was collected in total sampling. Thus, this study exclusively involved inpatients better monitoring.

The study inclusion criteria were all patients diagnosed with psoriasis who prescribed with methotrexate therapy at $10-15 \mathrm{mg}$ per week in three doses at $12 \mathrm{~h}$ intervals for 3-4 weeks. The laboratory examination included the number of erythrocytes, leukocytes, platelets, SGOT, SGPT, and clinical complaints of patients to see the side effects caused by methotrexate. Patients were examined (laboratory test) every 1 week before treated with methotrexate.

This study has obtained ethical clearance from the Health Research Ethics Committee of Dr. Soetomo General Academic Hospital Surabaya. This study was conducted at the central medical record unit of Dr. Soetomo General Academic Hospital Surabaya.

\section{RESULT}

The number of psoriasis patients who received methotrexate therapy on January 2017 - December 2018 was 22 , including 12 male patients (54.6\%) and 10 female patients $(45.4 \%)$. The most common psoriasis was psoriasis vulgaris $(77.3 \%)$.

Twenty two psoriasis patients receiving methotrexate therapy; $4.5 \%$ had erythrocytes below normal, 27.3\% had leukocytes above normal, 13.6\% had platelets above normal, $18.2 \%$ had SGOT above normal, $22.8 \%$ had SGPT above normal, $18 \%$ experienced nausea, $9.1 \%$ experienced vomiting, $4.6 \%$ experienced headache, and $4.6 \%$ experienced shortness of breath.

Table 1. Sex of the psoriasis patients

\begin{tabular}{|c|c|c|c|}
\hline \multirow{2}{*}{ Sex } & \multicolumn{2}{|c|}{ Year } & \multirow{2}{*}{ Total $(\%)$} \\
\hline & 2017 & 2018 & \\
\hline Male & 7 & 5 & $12(54.6)$ \\
\hline Female & 8 & 2 & $10(45,6)$ \\
\hline Total (\%) & $15(68,2)$ & $7(31,8)$ & $22(100)$ \\
\hline
\end{tabular}

\section{Types of Psoriasis}

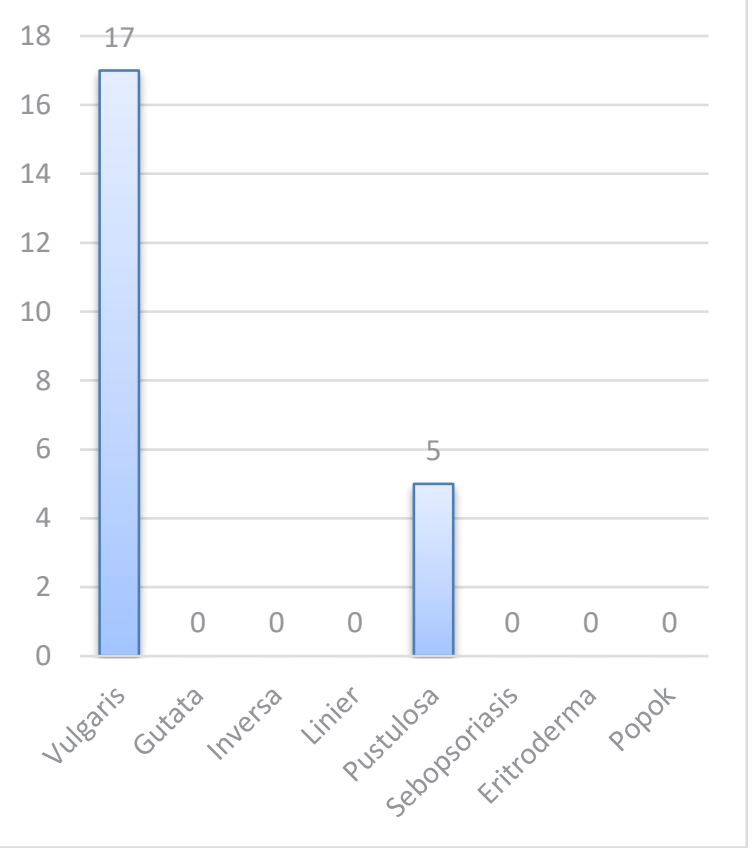

Figure 1. Types of psoriasis

Table 2. Erythrocyte level

\begin{tabular}{lc}
\hline \multicolumn{1}{c}{ Erythrocyte level } & Total $(\%)$ \\
\hline Above normal & 0 \\
Normal & \\
Normal - Increase & $9(40.9)$ \\
Normal - Constant & 0 \\
Normal - Decrease & $6(27.3)$ \\
Abnormal - Normal & $4(18.2)$ \\
Below normal & $1(4.5)$ \\
No data & $2(9.1)$ \\
\hline$\quad$ Total & $22(100)$ \\
\hline
\end{tabular}


The erythrocytes level of most patients after methotrexate therapy were found normal, $19(86.4 \%)$ patients. There was $1(4.5 \%)$ patient with erythrocytes level below normal.

Table 3. Leukocyte level

\begin{tabular}{lc}
\hline \multicolumn{1}{c}{ Leukocyte level } & Total (\%) \\
\hline Above normal & $6(27.3)$ \\
Normal & \\
Normal - Increase & $3(13.6)$ \\
Normal - Constant & $1(4.5)$ \\
Normal - Decrease & $6(27.3)$ \\
Abnormal - Normal & $4(18.2)$ \\
Below normal & 0 \\
No data & $2(9.1)$ \\
\hline Total & $22(100)$ \\
\hline
\end{tabular}

The leukocytes level of most patients after methotrexate therapy were observed normal, 14 $(63.6 \%)$ patients. Those who had leukocytes level above normal were $6(27.3 \%)$ patients.

Table 4. Thrombocyte level

\begin{tabular}{lc}
\hline \multicolumn{1}{c}{ Thrombocyte level } & Total $(\%)$ \\
\hline Above normal & $3(13.6)$ \\
Normal & \\
Normal - Increase & $10(45.5)$ \\
Normal - Constant & 0 \\
Normal - Decrease & $5(22.7)$ \\
Abnormal - Normal & $2(9.1)$ \\
Below normal & 0 \\
No data & $2(9.1)$ \\
\hline \multicolumn{1}{c}{ Total } & $22(100)$ \\
\hline
\end{tabular}

The thrombocytes level of most patients after methotrexate therapy were observed normal, which were $17(77.3 \%)$ patients. There were $3(13.6 \%)$ patients with thrombocytes level above normal.

Table 5. SGOT level

\begin{tabular}{lc}
\hline \multicolumn{1}{c}{ SGOT level } & Total $(\%)$ \\
\hline Above normal & $5(22.8)$ \\
Normal & \\
$\quad$ Normal - Increase & $9(40.9)$ \\
Normal - Constant & $1(4.5)$ \\
Normal - Decrease & $4(18.2)$ \\
Below normal & 0 \\
No data $\quad 3(13.6)$ \\
\hline \multicolumn{2}{c}{ Total } \\
SGOT $=$ Serum Glutamic Oxaloacetic Transaminase
\end{tabular}

The SGOT level of most patients after receiving methotrexate therapy were observed normal, which were $15(68.2 \%)$ patients, and there were $5(22.8 \%)$ patients with SGOT level above normal. Of the 5 patients with SGOT level above the normal limit, there were $2(40 \%)$ patients with 3 times increase of the initial value, $1(20 \%)$ patient with SGOT level increased 2 times from the initial value, and 2 (40\%) patients with a slight increasing of SGOT level. Of the 9 patients who experienced an increase in SGOT level, there was $1(11.1 \%)$ patient with SGOT level increased 2 times from the initial value but was still within the normal limit.

Table 6. SGPT level

\begin{tabular}{lc}
\hline \multicolumn{1}{c}{ SGPT level } & Total (\%) \\
\hline Above normal & $4(18.2)$ \\
Normal & \\
$\quad$ Normal - Increase & $10(45.5)$ \\
Normal - Constant & 0 \\
Normal - Decrease & $5(22.7)$ \\
Below normal & 0 \\
No data & $3(13.6)$ \\
\hline \multicolumn{1}{c}{ Total } & $22(100)$ \\
\hline
\end{tabular}

SGPT $=$ Serum Glutamic Pyvuric Transaminase

The SGPT level of most patients after receiving methotrexate therapy were found normal, which were $14(63.6 \%)$ patients, and there were $4(18.2 \%)$ patients with SGPT level above normal. Of the 4 patients who had SGPT level above the normal limit, there was 1 (25\%) patient with 3 increases from the initial value, 1 (25\%) patient with 5 increases from the initial value, 2 (50\%) patients with SGPT level above the normal limit but experiencing a slight increasing in SGPT level. Of the 10 patients with increased in SGPT level, there were $3(30 \%)$ patients with SGPT level increased 2 times from the initial value but was still within the normal limit.

Table 7. Clinical complaints

\begin{tabular}{lc}
\hline \multicolumn{1}{c}{ Clinical complaints } & Total (\%) \\
\hline Nausea & $4(18)$ \\
Vomiting & $2(9.1)$ \\
Headache & $1(4.6)$ \\
Shortness of breath & $1(4.6)$ \\
Epistaxis & $1(4.6)$ \\
No complaint & $13(59.1)$ \\
\hline Total & $22(100)$ \\
\hline
\end{tabular}

Most patients did not have clinical complaints after receiving methotrexate therapy, which were 13 $(59.1 \%)$ patients. 


\section{DISCUSSION}

The most common psoriasis was psoriasis vulgaris, which were 17 (77.3\%) patients, followed by pustular psoriasis with were $5(22.7 \%)$ patients. Guttate psoriasis, inverse psoriasis, linear psoriasis, sebopsoriasis, erythrodermic psoriasis, and diaper psoriasis were not found in this study. The results of this study are in accordance with the literature, stating that the most common form of psoriasis was psoriasis vulgaris at around $90 \%{ }^{2}$

There were $12(54.6 \%)$ male patients and 10 (45.6\%) female patients receiving methotrexate (MTX) therapy. The results of this study are almost in line with the literature, which states that there was no difference between the incidence of male and female patients. ${ }^{2}$ The age suffering the most from psoriasis and received MTX therapy $2017-2018$ was the age group of $46-$ 60 years old with 8 (36.4\%) patients. Previous studies stated that the prevalence of psoriasis was higher in adults than children with two peak ages: $30-39$ years old and 60 years old. The most of initial clinical features observed in psoriasis patients who received methotrexate therapy were erythematous macules with no firm boundaries with thick squama, with a total of $10(45.4 \%)$ patients, followed by erythematous macules with firm boundaries with thick squama found in $8(36.4 \%)$ patients.

In the laboratory assessment classified the effects of methotrexate as above normal, normal, and below the normal limit. The normal classifications were then divided into normal with level increase, constantly normal, normal with level decrease, and initially abnormal (above or below the normal limit). This was to distinguish increases within normal limits and increases above normal limits.

Methotrexate decreased the number of erythrocytes in psoriasis patients, which is in line with literature stating that methotrexate causes bone marrow suppression. ${ }^{14}$ In this study, only $4.5 \%$ of patients had below normal erythrocyte level, and no erythrocytes level abnormalities observed in the remainder. It was hypothesized that low-dose methotrexate $(<15-20$ $\mathrm{mg}$ /week) did not cause bone marrow abnormalities, which was an effective therapy for extensive and severe psoriasis and had minimal side effects if used carefully and regularly monitored. Methotrexate toxicity is dose-dependent, and low dose therapy is an effective therapy.

Twenty seven point three percent of patients were observed having the number of above normal leucocyte level. This occurred even before the methotrexate therapy. The $13.6 \%$ of patients had above normal platelet level before and after the therapy. It was also observed that the bone marrow suppression did not significantly affect leucocyte level that no changes were leading to normal or under limits. Therefore, the number of leukocytes, and platelets were still above normal limits.

Other methotrexate (MTX) side effects are the increasing of liver function consisting of SGOT and SGPT. Methotrexate therapy for a long time can cause hepatotoxicity. ${ }^{14}$ The risk of hepatotoxicity increases with concurrent alcohol consumption, obesity, diabetes mellitus, and cumulative doses of more than 3 grams methotrexate. ${ }^{15}$ The main cause of toxicity is the interaction with other drugs. Drug interactions will reduce protein binding or reduce renal clearance (for example, proton pump inhibitors) have been reported especially during high-dose methotrexate regimens. ${ }^{16}$

In this study, $68.2 \%$ of patients were observed having normal SGOT level after receiving methotrexate therapy, and only $18.2 \%$ of patients experienced an increase in SGOT level. Of $45.5 \%$ of patients had increased SGOT level within the normal limits. Most of the patients were also observed having normal SGPT level, which were $63.6 \%$ patients, and $40.9 \%$ of the patients experienced an increase in the number of SGPT level within normal limits. In average, SGOT level and SGPT level increased $3-4$ times. This is in accordance with the literature which states that methotrexate can increase the liver enzymes level. ${ }^{17}$

The National Institutes of Health suggested that the liver mechanism in managing methotrexateinduced toxicity is by inhibiting RNA and DNA synthesis and increasing liver stellate cells. ${ }^{18}$ Combination therapy of methotrexate and folic acid may inhibit liver enzymes production as long as the methotrexate is used in low dosage. Stellate cells stores vitamin A and plays a role in the occurrence of hepatic cirrhosis. $^{19}$

The psoriasis patients under methotrexate therapy reported the following complaints: nausea (18\%), vomiting $(4.6 \%)$, headache $(4.6 \%)$, shortness of breath (4.6\%), and epistaxis (4.6\%). On the other hand, $59.1 \%$ of patients reported no complaints. Prescribing folic acid, along with methotrexate, may can help to prevent clinical complaints. Folic acid minimizes the side effects such as nausea without reducing the effectiveness of methotrexate. ${ }^{2}$ Patients having epistaxis complaint might have a habit of manipulating the nose to bleed. Folic acis is given during the resting phase of methotrexate (MTX) administration, while taking methotrexate (MTX) is not allowed to take folic acid at the same time. ${ }^{20}$

Twenty two psoriasis patients receiving methotrexate therapy. It was observed that $4.5 \%$ erythrocytes level were below normal, 27.3\% leukocytes level were above normal, $13.6 \%$ platelets 
were above normal. Eighteen point two percent SGOT level were above normal, 22.8\% SGPT level were above normal. Eighteen percent of subjects experienced nausea, $9.1 \%$ experienced vomiting, $4.6 \%$ experienced headache, $4.6 \%$ experienced shortness of breath, and $59.1 \%$ did not experience clinical complaints. In this study, methotrexate may cause several side effects in some patients even not the severe ones; therefore careful dosing and side effect monitoring are necessary to minimize the side effects of methotrexate as a therapy in psoriasis patients.

\section{REFERENCES}

1. James, William D, Berger, Timothy G, Elston, Dirk M. Andrews' Diseases of the Skin: Clinical Dermatology. $11^{\text {th }}$ ed. London: Saunders /Elsavier. 2011. p. 190-6.

2. Gudjonsson JE, Elder JT. Psoriasiform Disorders. In: Kang S, Amagai M, Bruckner AL, Enk AH, Margolis DJ, McMichael AJ et al, editors. Fitzpatrick's dermatology in general medicine. 9th ed. New York: McGraw-Hill. 2019. p. 413-56.

3. World Health Organization. Global report on psoriasis. Switzerland. 2016.

4. Gayatri L and Ervianti E. Studi retrospektif: psoriasis pustulosa generalisata, Periodical of Dermatology and Venereology 2004; 26(1): 1-8.

5. Moningka A, Kandou RT, Niode NJ. Profil Psoriasis di Poliklinik Kulit dan Kelamin RSUP Prof. Dr. R. D. Kandou Manado Periode JanuariDesember 2012. Jurnal e-Clinic (eCI) 2015; 3(2): 646-50.

6. Kim W, Jerome D, Yeung J. Diagnosis and management of psoriasis. Canadian Family Physician 2017; 63(4): 278-85.

7. Haider S, Wahid Z, Saher NU, Riaz F. Efficacy of methotrexate in patients with plaque type psoriasis. Pakistan Journal of Medical Sciences 2014; 30(5): 1050-3.

8. Warren RB, Mrowietz U, Kiedrowski RV, Niesmann J, Wilsmann D, Ghoreschi K, et al. An intensified dosing schedule of subcutaneous methotrexate in patients with moderate to severe plaque-type psoriasis (METOP): a 52 week, multicentre, randomised, double-blind, placebocontrolled, phase 3 trial. Lancet 2017; 389 (10068): 528-37.

9. Nafiraldi, Sulistia Gain, 2016, Antikanker, Farmakologi dan Terapi. 6th ed. Jakarta: Balai Penerbit FK UI. 2016. p. 737-62.
10. Operacz MC, Przytocka AS, 2014. The possibilities and principles of methotrexate treatment of psoriasis - the updated knowledge. Advances in Dermatology and Allergology 2014; 31(6): 392-400.

11. Busard C, Menting S, Bezooijen S, Reek J, Hutten B, Prens E, et al. Optimizing adalimumab treatment in psoriasis with concomitant methotrexate (OPTIMAP): study protocol for a pragmatic, single-blinded, investigator-initiated randomized controlled trial. Trials 2017; 18(1):52-8.

12. Heller MM, Lee ES, Koo JYM. Stress as an influencing factor in psoriasis. Skin Therapy Letter $2011 ; 16(5)$ : 1-4.

13. Weidmann A, Foulkes AC, Kirkham N, Reynolds NJ. Methotrexate toxicity during treatment of chronic plaque psoriasis: a case report and review of the literature. Dermatol Ther (Heidelb) 2014; 4(2): 145-56.

14. Trevor AJ, Katzung BG, Masters SB, Hall MK. Katzung \& Trevors's Pharmacology Examination \& Board Review. New York: McGraw-Hill Companies. 2012. p. 469-3.

15. Pathirana D, Ormerod AD, Saiag P, Smith C, Spuls PI, Nast A, Barker J, et al. European S3Guidelines on the systemic treatment of psoriasis vulgaris. Journal of the European Academy of Dermatology and Venereology 2009; 24(1): 117 8.

16. Bezabeh S, Mackey AC, Kluetz P, Jappar D, Korvick J. Accumulating evidence for a drugdrug interaction between methotrexate and proton pump inhibitors. The Oncologis 2012; 17(4): 5504.

17. Wilmana PF, Sulistia G. Farmakologi dan terapi. Analgesik-antipiretik analgesik anti inflamasi non steroid dan obat gangguan sendi lainnya. 6th ed. Jakarta: Balai penerbit FK UI. 2016. p. 234-51.

18. National Institutes of Health. Overview Methotrexate. US. 2019.

19. Pattabang, Iola, \& Wangko, Sunny. Peran sel stelata hepatik pada sirosis hepatis. Jurnal Biomedik 2009; 1(1): 23-8.

20. Martodiharjo S. Pedoman Diagnosis dan Terapi Bag/SMF Ilmu Penyakit Kulit dan Kelamin. 3rd ed. Surabaya: FK Unair. 2005. p. 92-96. 